http:/ /dx.doi.org/10.1590/0104-07072017004820015

\title{
CONTENT VALIDATION OF NURSING OUTCOMES IN RELATION TO FAMILY CAREGIVERS: CONTENT VALIDATION BY BRAZILIAN AND COLOMBIAN EXPERTS
}

\author{
Leidy Johanna Rueda Diaz¹, Diná de Almeida Lopes Monteiro da Cruz², Rita de Cassia Gengo e Silva ${ }^{3}$
}

\footnotetext{
${ }^{1}$ Doctoral student, Escola de Enfermagem, Universidade de São Paulo (USP), Graduate Program in Adult Health Nursing. Fellow student, Capes' Graduate Fellowship, Brazil. Professor, Universidad Industrial de Santander, School of Nursing. Bucaramanga, Colombia. E-mail: johanna100603@gmail.com

2 Ph.D. in Nursing. Professor, Medical Surgical Nursing Department Escola de Enfermagem, USP. São Paulo, São Paulo, Brazil. E-mail: dinamcruz@usp.br

${ }^{3}$ Ph.D. in Cardiology. Professor, Medical Surgical Nursing Department, Escola de Enfermagem, USP. São Paulo, São Paulo, Brazil. E-mail: rita.gengo@usp.br
}

\begin{abstract}
Objective: this study's aim was to estimate the content validity of nursing outcomes in relation to family caregivers.

Method: eleven Brazilian and Colombian experts participated in the study. None of the 61 indicators of the four nursing outcomes were considered irrelevant; 42 (68.9\%) were considered primary and 19 (31.1\%) were considered secondary.

Results: the indicators with higher validity scores were: family share care responsibilities for Caregiver well-being (CVI=0.85); disruption of family dynamics to Caregiver lifestyle disruption $(\mathrm{CVI}=0.85)$; perceived spiritual well-being and anger for Caregiver emotional health $(\mathrm{CVI}=0.79)$ and perceived general health to Caregiver physical health $(\mathrm{CVI}=0.79)$.

Conclusion: the nursing outcomes studied had adequate content validity. It is recommended that content validation followed by clinical and construct validation of the nursing-sensitive outcomes be given in different cultures and care settings.

DESCRIPTORS: Nursing outcomes. Family caregivers. Validation studies. Nursing assessment. Classification.

\section{RESULTADOS DE ENFERMAGEM RELACIONADOS AO CUIDADOR FAMILIAR: VALIDAÇÃO DE CONTEÚDO POR EXPERTOS BRASILEIROS E COLOMBIANOS}

RESUMO

Objetivo: estimar a validade de conteúdo de quatro resultados de enfermagem relacionados ao cuidador familiar.

Método: onze expertos brasileiros e colombianos participaram do estudo. Nenhum dos 61 indicadores dos quatro resultados de enfermagem foi considerado irrelevante, 42 (68,9\%) foram considerados principais e 19 (31,1\%) foram considerados secundários.

Resultados: os indicadores com maiores escores de validade foram: família compartilhando as responsabilidades do oferecimento de cuidados para o Bem-estar do cuidador (IVC=0,85); ruptura da dinâmica familiar para a Ruptura do estilo de vida do cuidador (IVC $=0,85$ ); bem-estar espiritual percebido e raiva para Saúde emocional do cuidador $(I V C=0,79)$ e saúde geral percebida para Saúde física do cuidador (IVC=0,79).

Conclusão: os resultados de enfermagem estudados tiveram adequada validade de conteúdo. Recomenda-se que a validação de conteúdo, seguida pela validação clínica e de construto dos resultados ocorram em diferentes culturas e locais de assistência.

DESCRITORES: Resultados de enfermagem. Cuidador familiar. Estudos de validação. Avaliação em enfermagem. Classificação. 


\title{
RESULTADOS DE ENFERMERÍA RELACIONADOS CON EL CUIDADOR FAMILIAR: VALIDACIÓN DE CONTENIDO POR EXPERTOS BRASILEÑOS Y COLOMBIANOS
}

\begin{abstract}
RESUMEN
Objetivo: estimar la validez de contenido de cuatro resultados de enfermería relacionados con el cuidador familiar.

Método: once expertos brasileros y colombianos participaron en el estudio. Ninguno de los 61 indicadores de los cuatro resultados de enfermería fueron consideraos irrelevantes, $42(68,9 \%)$ fueron considerados principales y $19(31,1 \%)$ fueron considerados secundarios.

Resultados: los indicadores con mayores puntuaciones de validez fueron: familia compartiendo las responsabilidades del ofrecimiento de cuidados para el Bienestar del cuidador (IVC=0,85), ruptura de la dinámica familiar para Ruptura del estilo de vida del cuidador (IVC=0,85); bienestar percibido y rabia para Salud emocional del cuidador $($ IVC $=0,79)$ y salud general percibida para Salud física del cuidador (IVC $=0,79)$.

Conclusión: los resultados de enfermería tuvieron adecuada validez de contenido. Se recomienda que la validación de contenido seguida por la validación clínica y de constructo se realice en diferentes culturas y escenarios de cuidado.
\end{abstract}

DESCRIPTORES: Resultados de enfermería. Cuidadores familiares. Estudios de validación. Evaluación en enfermería. Clasificación.

\section{INTRODUCTION}

Caring for a family member with a chronic disease is an increasingly frequent activity in modern society. It is a stressful activity ${ }^{1-2}$ that imposes an important burden on caregivers and families. ${ }^{3-5}$ Family caregivers usually dedicate long periods of time meeting the physical, social and emotional needs of recipients of care, a situation that imposes restrictions on their own lives ${ }^{6}$ in such a way that they neglect their own self-care and interests. In addition to these restrictions, caregivers face various challenges, such as a lack or even absence of formal or informal support and/ or a lack of preparedness to provide care, ${ }^{7-8}$ harming the quality of care delivery.

Therefore, understandably, family caregivers require care that meets their own care demands. In this sense, nurses are supposed to devise care plans aiming to maintain the well-being of family caregivers, avoid disruption in their lifestyle, and to maintain their emotional and physical health. The effectiveness of a care plan can be estimated using outcomes measures and, for that, the Nursing Outcomes Classification (NOC) can be useful. ${ }^{9}$

Nursing outcomes should express valid measures to quantify the state of family caregivers. This has been a frequent concern among researchers and clinicians in the health field. In recent years, especially in Brazil, the number of studies addressing the validation of nursing outcomes has increased, though various authors ${ }^{10-11}$ have stressed that the number of such studies is still insufficient.

Note that none of the studies available in the literature that validates nursing outcomes has focused on family caregivers. This fact shows the need for further research in this particular area, developing and/or refining measure scales to quantify both the health status of caregivers and the effect of interventions proposed for people whose nursing diagnoses are related to family caregivers in different cultures, thereby advancing the state of knowledge concerning and development of NOC. Nursing outcomes validated in different languages and contexts enable comparing information with the same NOC outcome and also the development of multicenter studies conducted in different cultures.

This study's aim was to estimate the content validity of four nursing outcomes: Caregiver lifestyle disruption; Caregiver emotional health; Caregiver physical health; and Caregiver well-being.

\section{METHOD}

This content validity study focuses on NOC outcomes related to family caregivers. The model of diagnostic content validation proposed by Fehring ${ }^{12}$ was adapted for the validation of outcomes. This adaptation involved replacing the titles of diagnoses with the titles of outcomes, and the defining characteristics of diagnoses with outcome indicators. This model has been widely used in the nursing field. It is based on the opinion of expert nurses concerning the extent to which certain defining characteristics indicate a given diagnosis. In this study, the experts provided their opinions regarding the level of relevance of outcome indicators.

The sample was composed of Brazilian and Colombian nurses. The Brazilian experts were identified by searching online curricula in the Lattes Platform contained in the portal of the National Counsel of Technological and Scientific Development (CNPq) and the Colombian nurses were identified in the 
Directorio de Currículum Vitae en Ciencia y Tecnología (CvLAC) from October to November 2013.

The criteria proposed by Fehring ${ }^{12}$ to select experts were changed given the difficulty in meeting those criteria in the contexts where the study would be implemented. For instance, there are few nurses with a specialization in the field of outcomes that would be validated or with knowledge concerning nursing outcomes applied in clinical practice, teaching and/or research. Therefore, to be included in this study, it was determined that the experts should meet the following criteria: having at least one publication addressing diagnosis, intervention or nursing outcome or family caregivers; having a Master's or doctoral degree involving diagnosis, intervention or nursing outcome or in a field related to the care of people with chronic diseases or family caregivers; and having clinical practice of at least one year in fields related to the care of people with chronic disease or family caregivers. Exclusion criteria were: not completing the instrument according to the researchers' instructions or not returning the instrument within 30 days from the date consent was given to participate in the study.

After identifying the curricula and verifying inclusion criteria, 25 nurses were contacted by email and invited to participate. On this occasion, an invitation letter, an orientation guide, and the data collection instrument were also sent. Those who agreed to participate manifested their interest by email, as well. The orientation guide contained a summary of the antecedents concerning the subject and the manner in which the instrument should be completed. The document presented the indicators suggested by the NOC for each outcome with the respective conceptual and operational definitions previously established and validated. The experts judged how relevant each indicator was in regard to the outcome by using a five-point Likert scale: $1=$ absolutely non-characteristic, $2=$ not very characteristic, $3=$ somewhat characteristic, $4=$ considerably characteristic, and $5=$ very characteristic.

Data were collected between October $30^{\text {th }}$ 2013 and January $30^{\text {th }} 2014$. Ethical aspects followed Resolution No. 8.430/1993, Ministry of Health of the Republic of Colombia and Resolution No. 466/2012, Brazilian National Council of Health. This study was submitted to the Institutional Review Boards at the Universidad Industrial de Santander (Code No. 7083, on September $2^{\text {nd }} 2013$ ) and at the Universidade de
São Paulo, School of Nursing (Report No. 435.429, approved on October $8^{\text {th }}$ 2013). This study was supported by the São Paulo Research Foundation (FAPESP), process No. 2013/20744.

The sociodemographic variables were descriptively analyzed using absolute frequency (n) and percentage (\%). The weighted mean of the scores assigned by the experts was calculated to verify how relevant the indicators were in regard to the outcomes, considering the following weights for the levels of relevance: $1=0 ; 2=0.25 ; 3=0.50 ; 4=0.75$; $5=1 .^{11}$ The indicators that obtained means equal to or greater than 0.80 were considered to be primary indicators; those with a weight mean between 0.50 and 0.79 were considered secondary; and those with means equal to or lower than 0.49 were classified to be irrelevant. The total score for content validation was calculated for each outcome by totaling the individual scores of the indicators and dividing it by the total number of indicators of each outcome.

The Mann-Whitney test was used to estimate differences between the Brazilian and Colombian participants regarding the assessment of indicators of outcomes. The statistical analysis was conducted using the Statistical Package for the Social Sciences (SPSS) version 17.

\section{RESULTS}

Twelve of the 25 nurses contacted by email did not answer the invitation and two of them were excluded, while one of the participants did not complete the instrument according to the orientation provided in the invitation letter, and another returned the instrument after the due date. The final sample was, therefore, composed of 11 experts. Most were female ( $82 \%$ ), five ( $46 \%$ ) were Brazilian and six (54\%) were Colombian.

Eight $(73 \%)$ of the participant experts had a Master's degree. In regard to the research conducted in order to obtain the participants' highest academic degree, eight $(73 \%)$ had research related to the care of people with chronic disease or family caregivers. In terms of scientific production, most of the experts $(73 \%)$ had papers addressing the care of people with chronic disease and/or family caregivers.

The frequencies and percentages of the primary, secondary and irrelevant indicators of NOC outcomes according to the experts' assessment are presented in Table 1. 
Table 1 - Distribution of the number of indicators in the Nursing Outcomes Classification (NOC) relevant to family caregivers of individuals with chronic diseases according to level of relevance. São Paulo-SP, Brazil, 2014

\begin{tabular}{lcccc}
\hline NOC Outcomes & $\begin{array}{c}\text { NOC } \\
\text { indicators }\end{array}$ & $\begin{array}{c}\text { Primary } \\
\text { indicators }\end{array}$ & $\begin{array}{c}\text { Secondary } \\
\text { indicators }\end{array}$ & $\begin{array}{c}\text { Irrelevant } \\
\text { indicators }\end{array}$ \\
\hline Caregiver physical health & 16 & $7(44 \%)$ & $9(66 \%)$ & - \\
Caregiver emotional health & 15 & $11(73 \%)$ & $4(27 \%)$ & - \\
Caregiver lifestyle disruption & 16 & $10(63 \%)$ & $6(37 \%)$ & - \\
Caregiver well-being & 14 & $14(100 \%)$ & - & - \\
\hline
\end{tabular}

Of the indicators of the outcome Caregiver physical health, $44 \%(\mathrm{n}=7)$ were considered to be primary indicators and $66 \%(n=9)$ were considered secondary. Brazilian experts considered the indicator gastrointestinal function to be primary, while
Colombian experts considered it to be secondary $(0.95 \pm 0.11$ vs. $0.58 \pm 0.38$, respectively; $p=0.04)$. The same was observed in regard to the indicator blood pressure $(1.00 \pm 0$ vs. $0.50 \pm 0.42$, respectively; $p=0.03)$ (Table 2). The total score of content validity was 0.79 .

Table 2 - Indicators of the outcome Caregiver physical health, identified as primary and secondary according to scores obtained in the content validation. São Paulo-SP, Brasil, 2014

\begin{tabular}{|c|c|c|c|c|c|c|c|}
\hline \multirow{3}{*}{$\begin{array}{l}\text { Indicators } \\
\text { Perceived general health }\end{array}$} & \multicolumn{7}{|c|}{ Weighted mean (SD) } \\
\hline & \multicolumn{2}{|c|}{$\begin{array}{c}\text { Brazil } \\
n=5\end{array}$} & \multicolumn{2}{|c|}{$\begin{array}{c}\text { Colombia } \\
n=6\end{array}$} & \multicolumn{2}{|c|}{$\begin{array}{l}\text { Total } \\
\mathrm{n}=11\end{array}$} & \multirow{2}{*}{$\frac{\text { p-valor }}{0.64}$} \\
\hline & 0.95 & $(0.11)$ & 0.92 & $(0.13)$ & 0.93 & $(0.12)$ & \\
\hline Physical comfort & 0.90 & $(0.14)$ & 0.92 & $(0.13)$ & 0.91 & $(0.13)$ & 0.83 \\
\hline Sleep-rest pattern & 0.85 & $(0.22)$ & 0.92 & $(0.13)$ & 0.89 & $(0.17)$ & 0.67 \\
\hline Nutritional state & 1 & $(0)$ & 0.79 & $(0.25)$ & 0.89 & $(0.21)$ & 0.08 \\
\hline Cognitive state & 0.95 & $(0.11)$ & 0.83 & $(0.20)$ & 0.89 & $(0.17)$ & 0.28 \\
\hline Energy level & 0.85 & $(0.22)$ & 0.83 & $(0.20)$ & 0.84 & $(0.20)$ & 0.84 \\
\hline Mobility level & 0.95 & $(0.11)$ & 0.75 & $(0.27)$ & 0.84 & $(0.23)$ & 0.20 \\
\hline Physical fitness & 0.80 & $(0.21)$ & 0.75 & $(0.22)$ & 0.77 & $(0.21)$ & 0.70 \\
\hline Medication use & 0.80 & $(0.21)$ & 0.75 & $(0.32)$ & 0.77 & $(0.26)$ & 0.92 \\
\hline Gastrointestinal function & 0.95 & $(0.11)$ & 0.58 & $(0.38)$ & 0.75 & $(0.34)$ & 0.04 \\
\hline Cardiac function & 0.90 & $(0.14)$ & 0.63 & $(0.31)$ & 0.75 & $(0.27)$ & 0.09 \\
\hline Pulmonary function & 0.90 & $(0.14)$ & 0.63 & $(0.31)$ & 0.75 & $(0.27)$ & 0.09 \\
\hline Blood pressure & 1 & $(0)$ & 0.50 & $(0.42)$ & 0.73 & $(0.39)$ & 0.03 \\
\hline Physical function & 0.70 & $(0.21)$ & 0.67 & $(0.30)$ & 0.68 & $(0.25)$ & 0.85 \\
\hline Weight & 0.75 & $(0.18)$ & 0.58 & $(0.41)$ & 0.66 & $(0.32)$ & 0.57 \\
\hline Resistance to infection & 0.75 & $(0.25)$ & 0.50 & $(0.35)$ & 0.61 & $(0.32)$ & 0.22 \\
\hline
\end{tabular}

*Mann-Whitney test

Regarding the outcome Caregiver emotional health, $73 \%(n=11)$ of the indicators were considered primary and the remaining were considered secondary. No statistically significant differences were found between the assessments of Brazilian and Colombian experts (Table 3). The total score of content validity was 0.79 . 
Table 3 - Indicators of the outcome Caregiver emotional health identified as primary and secondary indicators according to the score obtained in content validation. São Paulo-SP, Brazil, 2014

\begin{tabular}{lccccccc}
\hline & \multicolumn{7}{c}{ Weighted mean (SD) } \\
\cline { 2 - 8 } Indicators & \multicolumn{2}{c}{ Brazil } & \multicolumn{2}{c}{ Colombia } & Total & p-value \\
& \multicolumn{2}{c}{$\mathbf{n}=5$} & \multicolumn{2}{c}{$\mathbf{n}=\mathbf{6}$} & n=11 & p $^{*}$ \\
\hline Perceived spiritual well-being & 0.95 & $(0.11)$ & 0.92 & $(0.13)$ & 0.93 & $(0.12)$ & 0.64 \\
Anger & 1 & $(0)$ & 0.88 & $(0.21)$ & 0.93 & $(0.16)$ & 0.18 \\
Guilt & 0.95 & $(0.11)$ & 0.88 & $(0.21)$ & 0.91 & $(0.17)$ & 0.56 \\
Frustration & 1 & $(0)$ & 0.83 & $(0.30)$ & 0.91 & $(0.23)$ & 0.18 \\
Ambivalence about situation & 0.95 & $(0.11)$ & 0.88 & $(0.21)$ & 0.91 & $(0.17)$ & 0.56 \\
Perceived burden & 0.95 & $(0.11)$ & 0.88 & $(0.14)$ & 0.91 & $(0.13)$ & 0.33 \\
Sense of control & 0.95 & $(0.11)$ & 0.79 & $(0.25)$ & 0.86 & $(0.21)$ & 0.24 \\
Self-esteem & 1 & $(0)$ & 0.75 & $(0.27)$ & 0.86 & $(0.23)$ & 0.08 \\
Depression & 0.75 & $(0.25)$ & 0.96 & $(0.10)$ & 0.86 & $(0.21)$ & 0.11 \\
Satisfaction with life & 0.90 & $(0.14)$ & 0.79 & $(0.33)$ & 0.84 & $(0.26)$ & 0.83 \\
Resentment & 0.90 & $(0.14)$ & 0.75 & $(0.32)$ & 0.82 & $(0.25)$ & 0.48 \\
Certainty about the future & 0.90 & $(0.22)$ & 0.67 & $(0.38)$ & 0.77 & $(0.33)$ & 0.24 \\
Perceived adequacy or resources & 0.75 & $(0.25)$ & 0.79 & $(0.25)$ & 0.77 & $(0.24)$ & 0.77 \\
Psychotropic medication use & 0.88 & $(0.14)$ & 0.67 & $(0.30)$ & 0.75 & $(0.26)$ & 0.26 \\
Perceived social connectedness & 0.80 & $(0.27)$ & 0.63 & $(0.34)$ & 0.70 & $(0.31)$ & 0.33 \\
\hline
\end{tabular}

*Mann-Whitney test

Table 4 shows that ten out of the $16(63 \%)$ indicators of the outcome Caregiver lifestyle disruption were considered to be primary and six (37\%) were considered secondary indicators. A statistically significant difference was found between the as- sessments of Brazilian and Colombian nurses only for the indicator relationship with a pet $(0.90 \pm 0.14$ vs. $0.42 \pm 0.20$, respectively; $\mathrm{p}<0.01)$. The total score of content validity was 0.85 .

Table 4 - Indicators of the outcome Caregiver lifestyle disruption identified as primary and secondary according to the scores obtained in the content validation. São Paulo-SP, Brazil, 2014

\begin{tabular}{|c|c|c|c|c|c|c|c|}
\hline \multirow{3}{*}{$\begin{array}{l}\text { Indicators } \\
\text { Disruption of family dynamics }\end{array}$} & \multicolumn{7}{|c|}{ Weighted mean (SD) } \\
\hline & \multicolumn{2}{|c|}{$\begin{array}{c}\text { Brazil } \\
\mathrm{n}=5\end{array}$} & \multicolumn{2}{|c|}{$\begin{array}{c}\text { Colombia } \\
n=6\end{array}$} & \multicolumn{2}{|c|}{$\begin{array}{l}\text { Total } \\
\mathrm{n}=11\end{array}$} & \multirow{2}{*}{$\frac{\text { p-value }^{*}}{0.33}$} \\
\hline & 0.95 & $(0.11)$ & 0.88 & $(0.14)$ & 0.91 & $(0.13)$ & \\
\hline Disruption of routine & 0.95 & $(0.11)$ & 0.83 & $(0.30)$ & 0.89 & $(0.23)$ & 0.56 \\
\hline Financial burden from caregiving & 0.90 & $(0.14)$ & 0.88 & $(0.21)$ & 0.89 & $(0.17)$ & 1 \\
\hline Role responsibilities & 0.90 & $(0.14)$ & 0.88 & $(0.21)$ & 0.89 & $(0.17)$ & 1 \\
\hline Role performance & 0.95 & $(0.11)$ & 0.83 & $(0.30)$ & 0.89 & $(0.23)$ & 0.56 \\
\hline Relationship with family members & 0.90 & $(0.14)$ & 0.83 & $(0.20)$ & 0.86 & $(0.17)$ & 0.61 \\
\hline Social support & 0.88 & $(0.14)$ & 0.80 & $(0.27)$ & 0.83 & $(0.22)$ & 0.79 \\
\hline Disruption of living environments & 0.90 & $(0.22)$ & 0.75 & $(0.22)$ & 0.82 & $(0.23)$ & 0.23 \\
\hline Diversional activities & 0.90 & $(0.22)$ & 0.75 & $(0.32)$ & 0.82 & $(0.28)$ & 0.34 \\
\hline Relationship with friends & 0.95 & $(0.11)$ & 0.71 & $(0.33)$ & 0.82 & $(0.28)$ & 0.20 \\
\hline Role flexibility & 0.80 & $(0.33)$ & 0.75 & $(0.32)$ & 0.77 & $(0.31)$ & 0.76 \\
\hline
\end{tabular}




\begin{tabular}{|c|c|c|c|c|c|c|c|}
\hline \multirow{3}{*}{$\begin{array}{l}\text { Indicators } \\
\text { Opportunities for privacy }\end{array}$} & \multicolumn{7}{|c|}{ Weighted mean (SD) } \\
\hline & \multicolumn{2}{|c|}{$\begin{array}{c}\text { Brazil } \\
n=5\end{array}$} & \multicolumn{2}{|c|}{$\begin{array}{c}\text { Colombia } \\
n=6\end{array}$} & \multicolumn{2}{|c|}{$\begin{array}{l}\text { Total } \\
\mathbf{n}=\mathbf{1 1}\end{array}$} & \multirow{2}{*}{$\frac{\text { p-value }}{\text { * }}$} \\
\hline & 0.85 & $(0.22)$ & 0.71 & $(0.25)$ & 0.77 & $(0.24)$ & \\
\hline Social interactions & 0.80 & $(0.21)$ & 0.75 & $(0.32)$ & 0.77 & $(0.26)$ & 0.92 \\
\hline Sleep & 0.75 & $(0.25)$ & 0.75 & $(0.39)$ & 0.75 & $(0.32)$ & 0.84 \\
\hline Work productivity & 0.80 & $(0.21)$ & 0.63 & $(0.26)$ & 0.70 & $(0.25)$ & 0.25 \\
\hline Relationship with a pet & 0.90 & $(0.14)$ & 0.42 & $(0.20)$ & 0.64 & $(0.30)$ & 0.00 \\
\hline
\end{tabular}

* Mann-Whitney test

Finally, the 14 indicators of the outcome Caregiver well-being were considered to be primary indicators. There were no statistically significant differences between the weighted means of the in- dicators of this outcome when comparing Brazilian and Colombian experts (Table 5). The total score of content validity was 0.87 .

Table 5 - Indicators of the outcome Caregiver well-being, identified as primary according to score obtained in the content validity. São Paulo-SP, Brazil, 2014

\begin{tabular}{|c|c|c|c|c|c|}
\hline \multirow{3}{*}{$\begin{array}{l}\text { Indicators } \\
\text { Family sharing of responsibilities for caregiving }\end{array}$} & \multicolumn{5}{|c|}{ Weighted mean (SD) } \\
\hline & \multicolumn{2}{|c|}{$\begin{array}{c}\text { Brazil } \\
n=5\end{array}$} & $\begin{array}{c}\text { Colombia } \\
n=6\end{array}$ & $\begin{array}{l}\text { Total } \\
\mathrm{n}=11\end{array}$ & \multirow{2}{*}{$\frac{\text { p-value }}{0.08}$} \\
\hline & 1.00 & $(0)$ & $0.88(0.14)$ & $0.93(0.12)$ & \\
\hline Social relationships & 0.95 & $(0.11)$ & $0.88(0.21)$ & $0.91(0.17)$ & 0.56 \\
\hline Availability for respire & 0.95 & $(0.11)$ & $0.88(0.14)$ & $0.91(0.13)$ & 0.33 \\
\hline Ability to cope & 1 & $(0)$ & $0.83(0.20)$ & $0.91(0.17)$ & 0.08 \\
\hline Lifestyle & 0.95 & $(0.11)$ & $0.83(0.26)$ & $0.89(0.21)$ & 0.48 \\
\hline Psychological health & 0.85 & $(0.22)$ & $0.88(0.21)$ & $0.86(0.21)$ & 0.83 \\
\hline Performance of usual roles & 0.9 & $(0.14)$ & $0.83(0.20)$ & $0.86(0.17)$ & 0.61 \\
\hline Social support & 0.75 & $(0.25)$ & $0.96(0.10)$ & $0.86(0.21)$ & 0.11 \\
\hline Health professional support & 0.8 & $(0.11)$ & $0.92(0.20)$ & $0.86(0.17)$ & 0.12 \\
\hline Financial resources for caregiving & 0.9 & $(0.14)$ & $0.83(0.30)$ & $0.86(0.23)$ & 1 \\
\hline Physical health & 0.75 & $(0.35)$ & $0.92(0.13)$ & $0.84(0.26)$ & 0.52 \\
\hline Support to instrumental activities of daily living & 0.8 & $(0.33)$ & $0.83(0.20)$ & $0.82(0.25)$ & 0.92 \\
\hline Caregiver role & 0.65 & $(0.29)$ & $0.92(0.20)$ & $0.80(0.27)$ & 0.07 \\
\hline
\end{tabular}

* Mann-Whitney test

\section{DISCUSSION}

The results concerning the content validation conducted by Brazilian and Colombian experts of four NOC outcomes related to family caregivers provide evidence that the indicators are relevant to their respective outcomes, even though we expected some indicators that were considered to be secondary ones to obtain scores greater than 0.80 . This is the case of the indicators of the outcome Caregiver physical health: physical fitness, blood pressure, medication use, resistance to infection, physical function, weight, gastrointestinal function, cardiac function, and pulmonary function. These indicators represent health parameters, which together, denote the physical wellbeing of family caregivers. Different studies agree that family caregivers present health disorders such as decreased immunological function, ${ }^{13}$ increased cardiovascular reactivity, ${ }^{14}$ increased blood pressure ${ }^{15}$ weight loss or gain. ${ }^{16}$

Stress accruing from delivering care affects various health dimensions of caregivers, including self-perception of health ${ }^{17}$ and the use of medica- 
tion. ${ }^{18}$ One study shows that caregivers experience an increase in negative symptoms by one third after assuming the responsibility of providing care. Additionally, spouse caregivers also report an increase in infectious diseases, especially those in the upper respiratory tract. ${ }^{19}$

The indicators anger, guilt, ambivalence about situation, depression, resentment, feeling of control, self-esteem, satisfaction with life, perceived spiritual well-being, frustration, and perceived burden, which belong to the outcome Caregiver emotional health, were considered by the experts to be primary indicators (Table 3). These indicators characterize the feelings and the subjective assessment of family caregivers. Caregivers present higher levels of depression symptoms and emotional distress ${ }^{17,20-21}$ and lower levels of self-acceptance and satisfaction with life, ${ }^{22}$ in addition to feeling as though they have less control over life $\mathrm{e}^{17,21}$ in comparison to non-caregivers. The stress experienced by family caregivers due to deprivation, responsibilities and care demands can result in anger, guilt, resentment, sorrow ${ }^{23}$ and a desire to get rid of the cause of stress by sending the recipient of care to an instituion. ${ }^{24-25}$ The responsibility to provide can also cause a sense of loss of identity, lower levels of self-esteem, constant concern or uncertainty. ${ }^{26}$ On the other hand, feelings of spiritual well-being can decrease the perception of burden among caregivers and are positively related to the caregivers' mental health. ${ }^{27}$ Frustration and burden $^{28-29}$ are frequently reported by caregivers while providing care.

Most indicators of the result Caregiver lifestyle disruption were considered primary indicators, suggesting how important these aspects were considered by the experts when assessing the impact of care on the lifestyle of family caregivers. The responsibility to provide care can negatively impact caregivers' privacy and ability to participate in activities like work, recreation, and social relationships, among others. ${ }^{30}$ This sort of interference can change one's routine, attitudes, habits and the way of life of caregivers, ${ }^{31}$ which may affect one's wellbeing. The fact the Colombian experts considered the indicator Relationship with a pet as non-relevant to the outcome drew our attention, though none of the experts justified this perception.

All the indicators concerning the outcome Caregiver well-being were considered primary indicators (Table 5), which indicates that all aspects being assessed are relevant. The items composing this outcome configure different dimensions of caregiver well-being, including health, support, social relationships and time to rest. The availability of informal support provided by family and friends, and formal support (healthcare professionals) favors family adaptation, ${ }^{32}$ decreases care burden and improves quality of life, ${ }^{23}$ while social relationships give meaning to life and increase caregivers' feeling of safety, as well as that of the individual receiving care. ${ }^{33}$ Caregivers who have time to rest are able to restore their energy, which decreases the impact of care on their health and improves their well-being. ${ }^{34}$

Differences in the judgments of Brazilian and Colombian experts regarding the level of relevance of the indicators gastrointestinal function and blood pressure from the outcome Caregiver physical health (Table 2), as well as the indicator relationship with a pet from the outcome Caregiver lifestyle disruption (Table 4), may be related to differences in professional backgrounds and sociocultural contexts, an aspect that could be the object of other investigations.

All the outcomes obtained adequate total scores for validity (above 0.79). Fehring ${ }^{12}$ holds that total scores of validity greater than 0.60 are appropriate. Note that these scores were calculated based on the opinions of nurses from different sociocultural contexts and were nevertheless considered adequate.

The content validation of the outcomes Caregiver well-being, Caregiver emotional health, Caregiver physical health, and Caregiver lifestyle disruption by experts from two different cultures makes a considerable contribution to knowledge in nursing and to refining the NOC. The nursing outcomes focus on assessing the perceptions of family caregivers regarding their health, physical and emotional well-being, and the severity of lifestyle changes accruing from the caregiver role. In fact, content validation of nursing outcomes provides evidence that attests to their use. This is important because valid indicators provide nurses with more accurate measures to assess the results of interventions. Additionally, this study's findings suggest that the indicators of the four outcomes are relevant to be used in different sociocultural contexts.

Even though estimates of content validity represent the extent to which an empirical measure reflects a specific domain, ${ }^{35}$ they are not sufficient to represent other types of validity. Further studies addressing construct validation, for instance, can provide more robust evidence regarding the validity of these results, especially if conducted in potentially different cultural contexts. The verification of similar estimates of validity of nursing outcomes in different contexts suggests there is cultural equivalence between the cultures in which they were assessed. 
This study's limitations include the relatively small number of experts, which limits the generalization of findings. The limited number of publications addressing NOC outcomes, especially in Colombia, may reflect limited skill and knowledge on the use of this classification. Such a fact may have influenced this study's findings.

\section{CONCLUSION}

This study presents evidence of proper content validity for four NOC outcomes related to family caregivers. Most indicators of the results assessed in this study were considered to be relevant by Brazilian and Colombian experts. Given the fact that validation studies contribute to the refinement and advancement of knowledge regarding the NOC, we recommend that content validation, followed by clinical and construct validation of outcomes, take place in different cultures and settings.

\section{REREFENCES}

1. Roth DL, Fredman L, Haley WE. Informal caregiving and its impact on health: a reappraisal from population-based studies. Gerontologist. 2015; 55(2):309-19.

2. Costa TF, Costa KN, Martins KP, Fernandes M, Brito S. Burden over family caregivers of elderly people with stroke. Esc Anna Nery [Internet]. 2015 [cited 2015 Dec 19]; 19(2):350-55. Available from: http:/ / www.scielo. br/scielo.php?-pid=S141481452015000200350\&script =sci_arttext\&tlng=en

3. Bevans MF, Sternberg EM. Caregiving burden, stress, and health effects among family caregivers of adult cancer patients. JAMA. 2012; 307(4):398-403.

4. Adelman RD, Tmanova LL, Delgado D, Dion S, Lachs MS. Caregiver burden: a clinical review. JAMA. 2014; 311(10):1052-60.

5. Bhimani R. Understanding the burden on caregivers of people with parkinson's: a scoping review of the literature. Rehabil Res Pract [Internet]. 2014 [cited 2014 Dec 20]; 2014:718527 Available from:https://www. hindawi.com/journals/rerp/2014/718527/

6. Fernandes MGM, Garcia TR. Determinantes da tensão do cuidador familiar de idosos dependentes. Rev Bras Enferm [Internet]. 2009 [cited 2014 Dec 20]; 62(1):57-63. Available from: http://www. scielo.br/scielo.php?script=sci_arttext\&pid=S003 71672009000100009\&lng=en

7. DuBenske LL, Gustafson DH, Namkoong K, Hawkins RP, Atwood AK, Brown RL, et al. CHESS improves cancer caregivers' burden and mood: results of an eHealth RCT. Health Psychol. 2014; 33(10):1261-72.

8. Mores G1, Whiteman R, Knobl P, Ploeg J, Cahn M, Klaponski L, et al. Pilot evaluation of the family informal caregiver stroke self-management program. Can J Neurosci Nurs. 2013; 35(2):18-26.

9. Moorhead S, Johnson M, Maas ML, Swanson E. Nursing outcomes classification (NOC). 5th ed. Saint Louis: Elsevier; 2013.

10. Almeida MA, Seganfredo DH, Barreto LN, Lucena AF. Validação de indicadores da nursing outcomes classification para adultos hospitalizados em risco de infecção. Texto Contexto Enferm [Internet]. 2014 [cited 2014 Nov 12]; 23(2):309-17. Available from: http:/ / www.scielo.br/pdf/tce/v23n2/pt_0104-0707tce-23-02-00309.pdf.

11. Garbin LM, Rodrigues C, Rossi LA, Carvalho EC. Classificação de resultados de enfermagem (NOC): identificação da produção científica relacionada. Rev Gaúch Enferm [Internet] 2009 [acesso 2014 Feb 2]; 30(03):508-15. Available from: http://seer. ufrgs.br/RevistaGauchadeEnfermagem/article/ view/8216\% 20/6971

12. Fehring R. Methods to validate nursing diagnoses. Hear lung. 1987;16(6 Pt 1):625-9.

13. Kiecolt-Glaser JK, Dura JR, Speicher CE, Trask OJ, Glaser R. Spousal caregivers of dementia victims: longitudinal changes in immunity and health. Psychosom Med. 1991; 53(4):345-62.

14. Mausbach BT, Patterson TL, Rabinowitz YG, Grant I, Schulz R. Depression and distress predict time to cardiovascular disease in dementia caregivers. Heal Psychol. 2007; 26(5):539-44.

15. Torimoto-Sasai Y1, Igarashi A, Wada T, Ogata Y, Yamamoto-Mitani N. Female family caregivers face a higher risk of hypertension and lowered estimated glomerular filtration rates: a cross-sectional, comparative study. BMC Public Health. 2015; 15:17.

16. Beesley VL, Price MA, Webb PM. Loss of lifestyle: health behaviour and weight changes after becoming a caregiver of a family member diagnosed with ovarian cancer. Support Care Cancer. 2011; 19(12):1949-56.

17. Pinquart M, Sörensen S. Gender differences in caregiver stressors, social resources, and health: an updated meta-analysis. J Gerontol B Psychol Sci Soc Sci. 2006; 61(1):33-45.

18. Camargos EF, Souza AB, Nascimento AS, Morais AC, Quintas JL, Louzada LL, et al. Use of psychotropic medications by caregivers of elderly patients with dementia : is this a sign of caregiver burden? Arq Neuro-Psiquiatr [Internet]. 2011 [cited 2014 Feb 3]; 70(3):169-74. Available from: http://www.scielo. br $/$ scielo.php? script $=$ sci_arttext $-\&$ pid $=$ S0004282X2012000300003\&lng=en

19. Esterling BA, Kiecolt-Glaser JK, Glaser R. Psychosocial Modulation of cytokine-lnduced natural killer cell activity in older adults. Psychosom Med. 1996; 28:264-72.

20. Sallim AB, Sayampanathan A, Cuttilan A, Chun-Man Ho R. Prevalence of mental health disorders among caregivers of patients with alzheimer disease. J Am Med Dir Assoc. 2015; 16(12):1034-41. 
21. Marks N, Lambert J, Choi H. Transitions to caregiving, gender, and psychological well- being : a prospective U.S. National Study. J Marriage Fam. 2002; 64:657-67.

22. Borg C, Hallberg I. Life satisfaction among informal caregivers in comparison with non-caregivers. Scand J Caring Sci. 2006; 20(4):427-38.

23. Rabow MW, Hauser JM, Adams J. Supporting family caregivers at the end of life: "they don't know what they don't know". JAMA. 2004; 291(4):483-91.

24. Gaugler J, Leitsch S, Zarit SH, Pearlin LI. Caregiver involvement following institutionalization: effects of preplacement stress. Res Aging. 2000; 22(4):337-59.

25. Araújo O, Lage I, Cabrita J, Teixeira L. Intervention in informal caregivers who take care of older people after a stroke (InCARE): study protocol for a randomised trial. J Adv Nurs. 2015; 71(10):2435-43.

26. Center on Aging Society. How do family caregivers fare? a closer look at their experiences. [Internet] 2005 [cited $2014 \mathrm{Feb} 22]$; 3. Available from: http://www. nasuad.org/sites/nasuad/files/hcbs/files/73/3647/ CAREGIVERS3.pdf.

27. Yeh PM, Bull M. Influences of spiritual well-being and coping on mental health of family caregivers for elders. Res Gerontol Nurs. 2009; 2(3):173-81.

28. Baider L, Surbone A. Universality of aging: family caregivers for elderly cancer patients. Front Psychol. 2014; 5:744.

29. Narayan SM, Varghese M, Hepburn K, Lewis M, Paul I, Bhimani R. Caregiving experiences of family members of persons with dementia in south India. Am J Alzheimers Dis Other Demen. 2015; 30(5):508-16.
30. Cameron JI, Franche R-L, Cheung AM, Stewart DE. Lifestyle interference and emotional distress in family caregivers of advanced cancer patients. Cancer. 2002; 94(2):521-7.

31. Dione FS, Comassetto I, Magalhães APN, Faro AC, Moreira RT, Soares EM. The experience of the family caregiver of a traffic accident victim with functional disability. J Nurs UFPE on line [Internet]. 2014 [cited 2014 Dec 01]; 9(Suppl 1):343-50. Available from: http:/ / www.revista.ufpe.br/revistaenfermagem/ index.php/revista/article/view/5918/pdf_7013

32. Simon B, Budó ML, Garcia R, Gomes T, Oliveira G, Moreira M. Rede de apoio social à família cuidadora de indivíduo com doença crônica : revisão integrativa. Rev enferm UFPE [Internet]. 2013 [cited 2014 Dec 01]; 7(spe):4243-50. Available from: http://www.revista. ufpe.br/revistaenfermagem/index.php/revista/ article/view/4181/pdf_2643

33. Yamashita $\mathrm{CH}$, Amendola F, Gaspar JC, Alvarenga MRM, Oliveira MADC. Associação entre o apoio social e o perfil de cuidadores familiares de pacientes com incapacidades e dependência. Rev Esc Enf USP. 2013; 47(6):1359-66.

34. Tzuh-Tang S, Ly CY. The important role of sense of coherence in relation to depressive symptoms for Taiwanese family caregivers of cancer patients at the end of life. J Psychosom Res. 2008; 64(2):195-203.

35. Díaz Heredia LP1, Muñoz Sánchez AI, de Vargas D. Reliability and validity of spirituality questionnaire by Parsian and Dunning in the Spanish version. Rev Latino-Am Enfermagem. 2012; 20(3):559-66.
Correspodence: Leidy Johanna Rueda Díaz

Universidad Industrial de Santader, Escuela de Enfermería Carrera 32 No. 29-31 Piso 5

680002 - Apartado aéreo No. 40598, Bucaramanga, Colômbia

E-mail: johanna100603@gmail.com
Received: October 10, 2015

Approved: May 05, 2016 